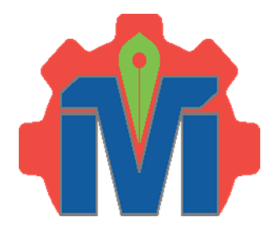

JMI Vol. 38 No. 2 Desember 2016

METAL INDONESIA

Journal homepage:

http://www.jurnalmetal.or.id/index.php/jmi

p-issn: $0126-3463$

e-issn : 2548-673X

\title{
PERANCANGAN ULANG TATA LETAK FASILITAS LABORATORIUM PENGUJIAN BALAI BESAR LOGAM DAN MESIN
}

\section{REDESIGN OF TESTING LABORATORY FACILITIES LAYOUT IN BALAI BESAR LOGAM DAN MESIN}

\author{
Mirantie Dwiharsanti, Gugum Gumilar, Hendri Siswanto \\ Balai Besar Logam dan Mesin, Kementerian Perindustrian \\ Jalan Sangkuriang No. 12 Bandung 40135 \\ E-mail: rantie_25@yahoo.com
}

\begin{abstract}
Abstrak
Balai Besar Logam dan Mesin (BBLM) sebagai lembaga pengujian yang ditunjuk untuk pelaksanaan SNI Wajib selalu didukung dengan fasilitas mesin/alat uji.. Namun pengadaan fasilitas mesin/alat uji tidak didukung dengan perencanaan tata letak fasilitas yang baik. Mesin/alat uji ditempatkan tanpa memperhatikan fungsi mesin/alat uji. Berdasarkan masalah tersebut maka diperlukan perancangan ulang tata letak fasilitas laboratorium pengujian untuk mencapai metriks yang optimal. Penelitian ini menggunakan metode konvensional dalam melakukan perancangan ulang tata letak laboratorium pengujian. Berdasarkan analisa tata letak awal laboratorium pengujian kemudian dilakukan identifikasi fasilitas dan perhitungan luas lantai yang dibutuhkan. Setelah itu dilakukan analisa kedekatan fasilitas dengan membuat ARC (Activity Relationship Chart) dan menyusun ARD (Activity Relationship Diagram). Berdasarkan ARD kemudian dibuat template tata letak fasilitas laboratorium pengujian. Tata letak laboratorium pengujian disusun berdasarkan process layout dan product layout. Fasilitas yang disusun berdasarkan process layout adalah fasilitas pengujian kekerasan, spektrometer, struktur mikro dan makro, UTM, Impak, dan perparasi sampel. Sedangkan fasilitas yang disusun berdasarkan product layout adalah pengujian sepeda, kompor, dan regulator.
\end{abstract}

Kata Kunci:Tata letak fasilitas, Perencanaan tata letak konvensional, Tata letak laboratorium

\begin{abstract}
Balai Besar Logam dan Mesin (BBLM) as the testing institution assigned in implementing SNI wajib is always supported with testing facility. However, the provision of testing facility is not supported with good facility layout planning. Testing facilities are placed regardless of their function. Based on those problem, it is necessary to redesign testing laboratory facilities in order to optimize a desired metric. The research uses conventional method to redesign testing laboratory layout. Identification of facility and calculation of needed floor area are carried out based on the analysis of initial testing laboratory layout. Then the analyze of facility proximity is carried out by making the ARC (Activity Relationship Chart) and arrange the ARD (Activity Relationship Diagram). Based on ARD testing laboratory layout template is made. Testing laboratory is arrange based on process layout and product layout. Facility arranged based on process layout are hardness testing, spectrometer, micro and macro structure, UTM, impact and sample preparation. While the facility arranged based on product layout are testing of bicycle, stove, and regulator.
\end{abstract}

Keywords: Facilities Layout, Conventional Layout Planning, Laboratory layout 


\section{PENDAHULUAN}

Tata Letak Fasilitas merupakan salah satu faktor yang berpengaruh terhadap efesiensi aktivitas produksi (Indrianti, Marya, \& Ristono, 2011). Penelitian mengenai perancangan tata letak fasilitas laboratorium pengujian belum pernah dilakukan sebelumnya.Perancangan tata Perindustrian merupakan lembaga yang salah satu fungsinya sebagai lembaga pengujian terakreditasi yang ditunjuk dan ditetapkan dalam rangka mendukung SNI wajib.

BBLM sebagai lembaga pengujian yang ditunjuk dalam rangka melaksanakan SNI wajib selalu didukung dengan fasilitas mesin/alat uji untuk kelancaran pelaksanaan SNI Wajib. Laboratorium pengujian BBLM memiliki 45 lingkup pengujian yang terakreditasi KAN.

Namun pengadaan fasilitas mesin/alat uji tidak didukung dengan perencanaan tata letak fasilitas yang baik. Mesin/alat uji diletakkan tanpa memperhatikan keterkaitan pengujian, keterkaitan pegawai/operator, dan aliran informasi. Mesin/alat uji yang memiliki fungsi yang sama diletakkan berjauhan begitu pula untuk mesin/alat uji untuk menguji satu produk yang sama pun diletakkan berjauhan. Hal tersebut mengakibatkan operator uji harus berjalan dengan jarak yang lebih jauh dalam mencapai alat/mesin uji. Selain itu juga laboratorium pengujian BBLM tidak mempunyai ruang khusus tempat penyimpanan sampel uji sehingga banyak sampel uji yang diletakkan di sembarang tempat dan menutupi ruang beberapa mesin/alat uji. Masalah tata letak fasilitas merupakan salah satu faktor yang berperan penting dalam peningkatan produktivitas (Qoriyana dkk, 2014). Masalah tata letak fasilitas berkaitan dengan mengatur sekumpulan departemen (fasilitas, stasiun kerja, mesin) dalam batas luas lantai yang diberikan untuk mencapai metriks yang optimal dan berkaitan dengan biaya penanganan material (Sarin, Wang, \& Wang, 2009). Berdasarkan masalah tersebut maka diperlukan perancangan ulang tata letak fasilitas laboratorium pengujian untuk mencapai metriks yang optimal.

\section{METODE}

Perancangan tata letak laboratorium pengujian mengadopsi metode perancangan tata letak pabrik. Terdapat beberapa teknik yang umum digunakan dalam perancangan tata letak (Apple, 1990) diantaranya adalah teknik konvensional. Tahapan metode teknik konvensional dapat dilihat pada Gambar.1 letak fasilitas laboratorium pengujian berbeda dengan tata letak fasilitas produksi karena aliran pekerjaan pengujian tidak harus berurutan sedangkan aliran pekerjaan pada produksi selalu berurutan. Balai Besar Logam dan Mesin (BBLM) sebagai salah satu unit eselon dua dibawah Kementerian

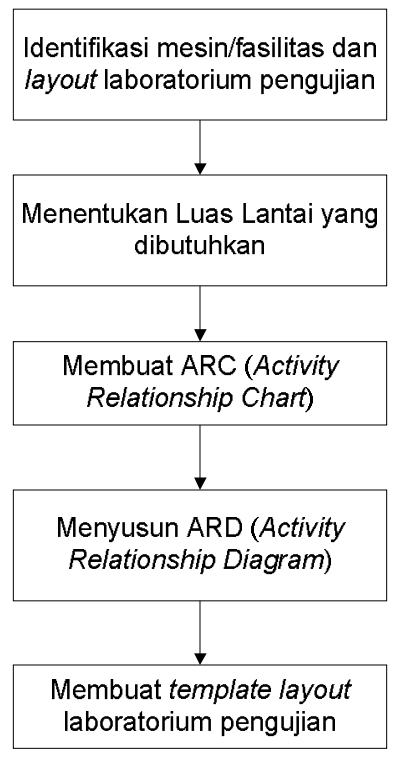

Gambar 1. Metode penelitian

Dalam tata letak pabrik ada 2 hal yang diatur letaknya yaitu pengaturan mesin dan pengaturan departemen (wignjosoebroto, 1996) sehingga tahapan pertama yang dilakukan adalah mengidentifikasi mesin pengujian dan departemen yang ada beserta ukurannya serta membuat layout laboratorium pengujian existing. Tahapan yang kedua adalah menentukan luas lantai yang dibutuhkan. Dimana luas lantai dihitung berdasarkan ukuran mesin pengujian ditambahkan dengan luas ruang operator dan kelonggaran. Kelonggaran diberikan dalam bentuk persentase terhadap luas area. Kelonggaran untuk operator dan gang diberikan sebesar 150\% dari luas mesin (Apple, 1990). Namun karena penelitian ini luas lantai operator telah dihitung sehingga besar kelonggaran yang diberikan adalah $100 \%$ dari luas total. Kelonggaran ini ditambahkan sebagai luas area untuk gang, tempat penyimpanan sementara sampel uji, dan untuk keluwesan apabila diperlukan penambahan kapasitas.

Tahapan ketiga adalah membuat ARC (Activity Relationship Chart) yaitu menentukan hubungan antar mesin/fasilitas pengujian dengan berdiskusi dan wawancara dengan operator pengujian. Hubungan antar fasilitas sering ditafsirkan sebagai persyaratan kedekatan 
(Tompkins, White, Bozer, Frazelle, Tanhoco, \& JaimeTrevino, 1996). Jika ada dua mesin/fasilitas memiliki hubungan yang kuat maka mesin/fasilitas tersebut perlu diletakkan berdekatan dan sebaliknya. Nilai hubungan kedekatan ditentukan berdasarkan Tabel 1 .

Tabel 1. Nilai Hubungan Kedekatan (Tompkins, White, Bozer, Frazelle, Tanhoco, \& JaimeTrevino, 1996)

\begin{tabular}{|c|l|}
\hline Nilai & \multicolumn{1}{|c|}{ Kedekatan } \\
\hline A & Absolutely Necessary \\
\hline E & Especially Important \\
\hline I & Important \\
\hline O & Ordinary closeness okay \\
\hline U & Unimportant \\
\hline $\mathrm{X}$ & Undesirable \\
\hline
\end{tabular}

Alasan kedekatan yang digunakan antara lain urutan aliran kerja, menggunakan operator yang sama, dan menggunakan catatan yang sama.

Tahapan keempat adalah menyusun ARD (Activity Relationship Diagram) yaitu menyusun diagram balok yang menunjukkan kedekatan fasilitas. ARD disusun berdasarkan hasil dari ARC. Tahap terakhir adalah membuat template relayout laboratorium pengujian berdasarkan ARD yang telah disusun.

\section{HASIL DAN PEMBAHASAN}

Laboratorium pengujian terdiri dari dua gedung yang berbeda yaitu gedung laboratorium yang lama dan gedung laboratorium yang baru yang memiliki 2 lantai. Pada Laboratorium lama memiliki luas $26,5 \times 12 \mathrm{~m}$ yang terdapat mesin uji kekerasan, mesin dartek, alat uji struktur rem sepeda, alat uji impak, alat uji UTM, uji relaksasi, mesin freis, mesin bubut, dan gudang. Pada laboratorium baru lantai 1 memiliki luas $18 \times 10 \mathrm{~m}$ yang terdapat alat uji sepeda, alat uji spectrometer, ball joint, cross joint. Pada Laboratorium baru lantai 2 memiliki luas $21 \mathrm{x}$ $10 \mathrm{~m}$ yang terdapat lab uji kompor, lab uji struktur mikro dan makro, lab uji regulator, ruang asam, ruang rapat, dan gudang. Layout laboratorium pengujian saat ini dapat dilihat pada gambar 2,3, dan 4 .

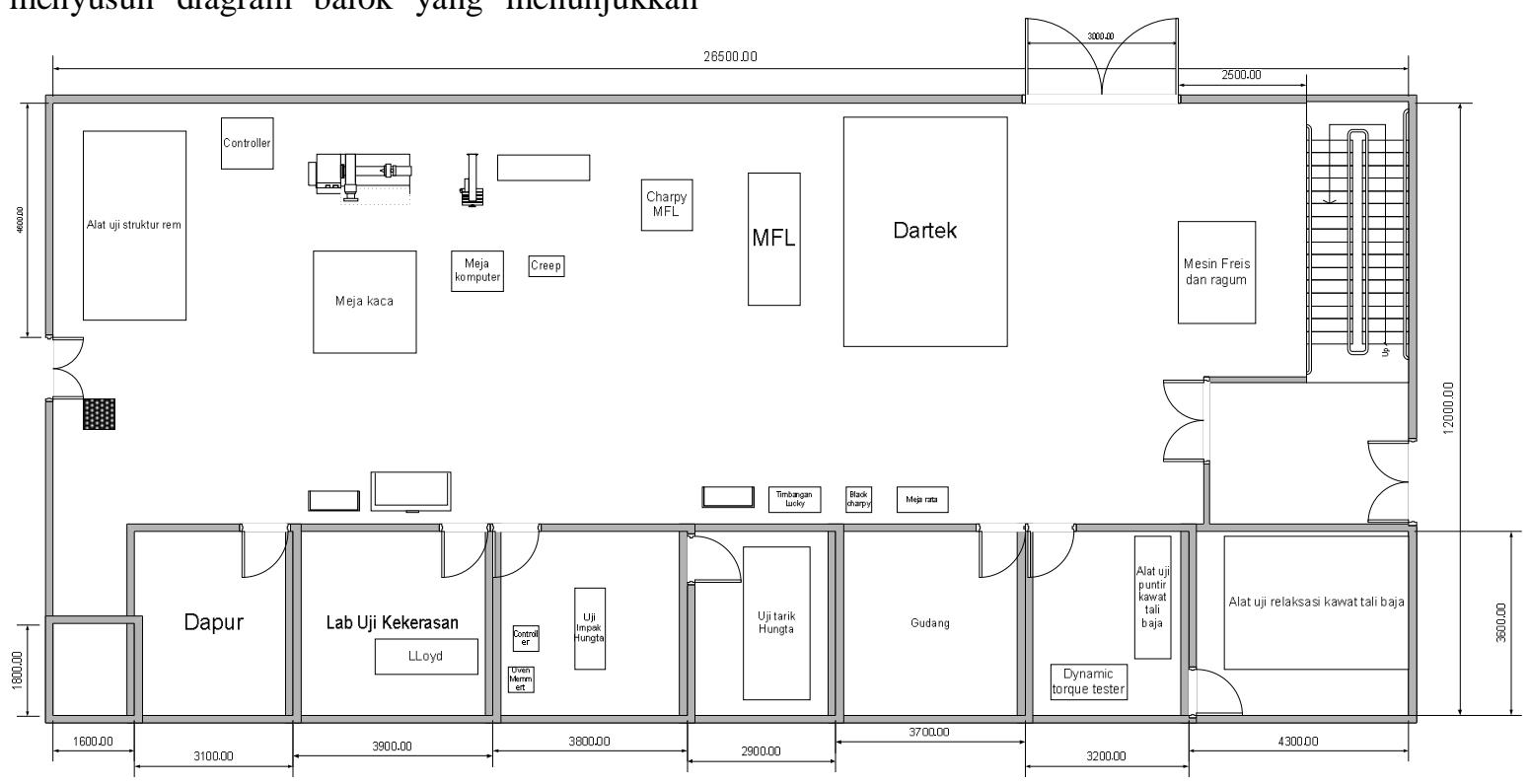

Gambar 2. Layout awal laboratorium pengujian lama 


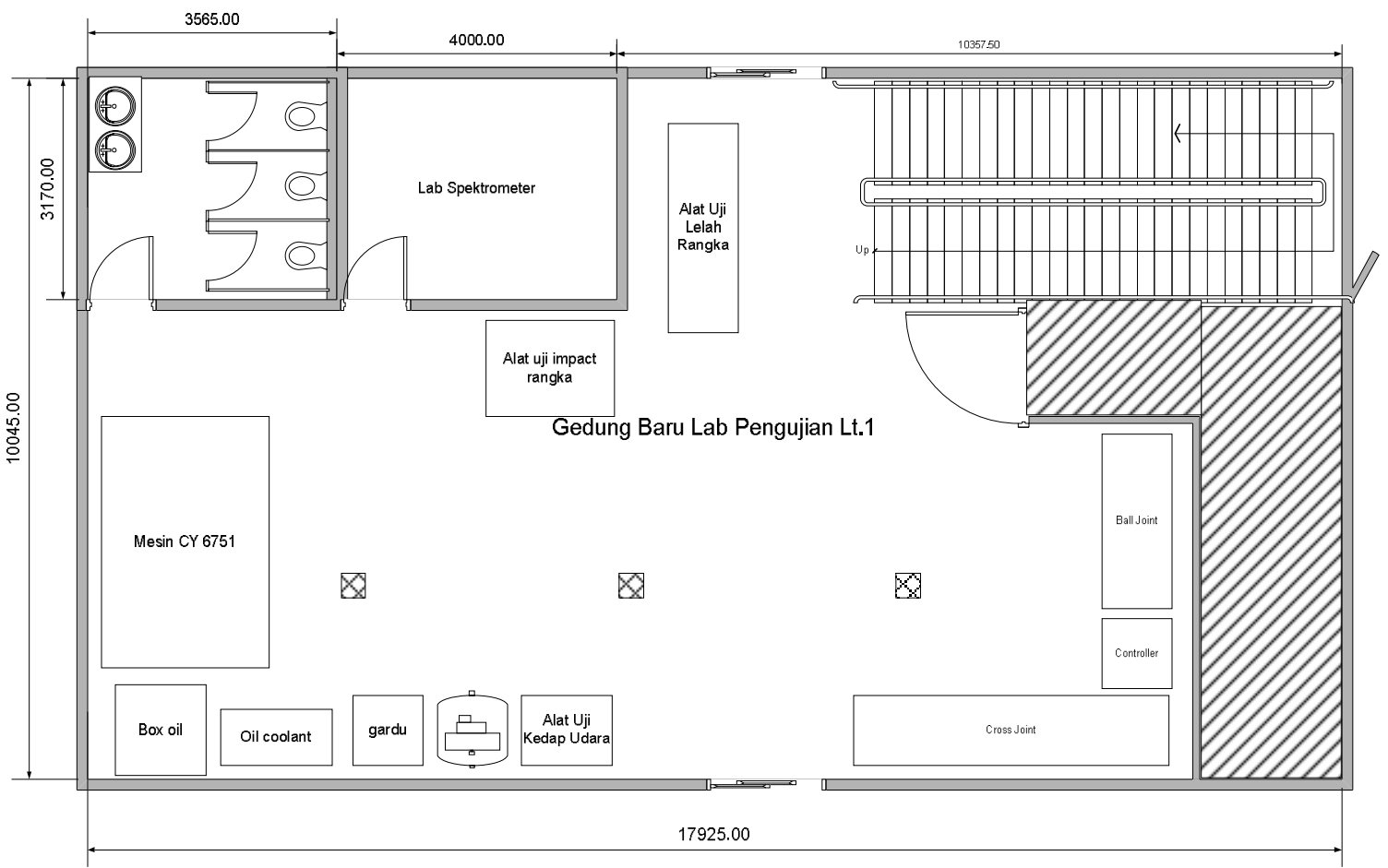

Gambar 3. Layout awal laboratorium pengujian baru lt.1

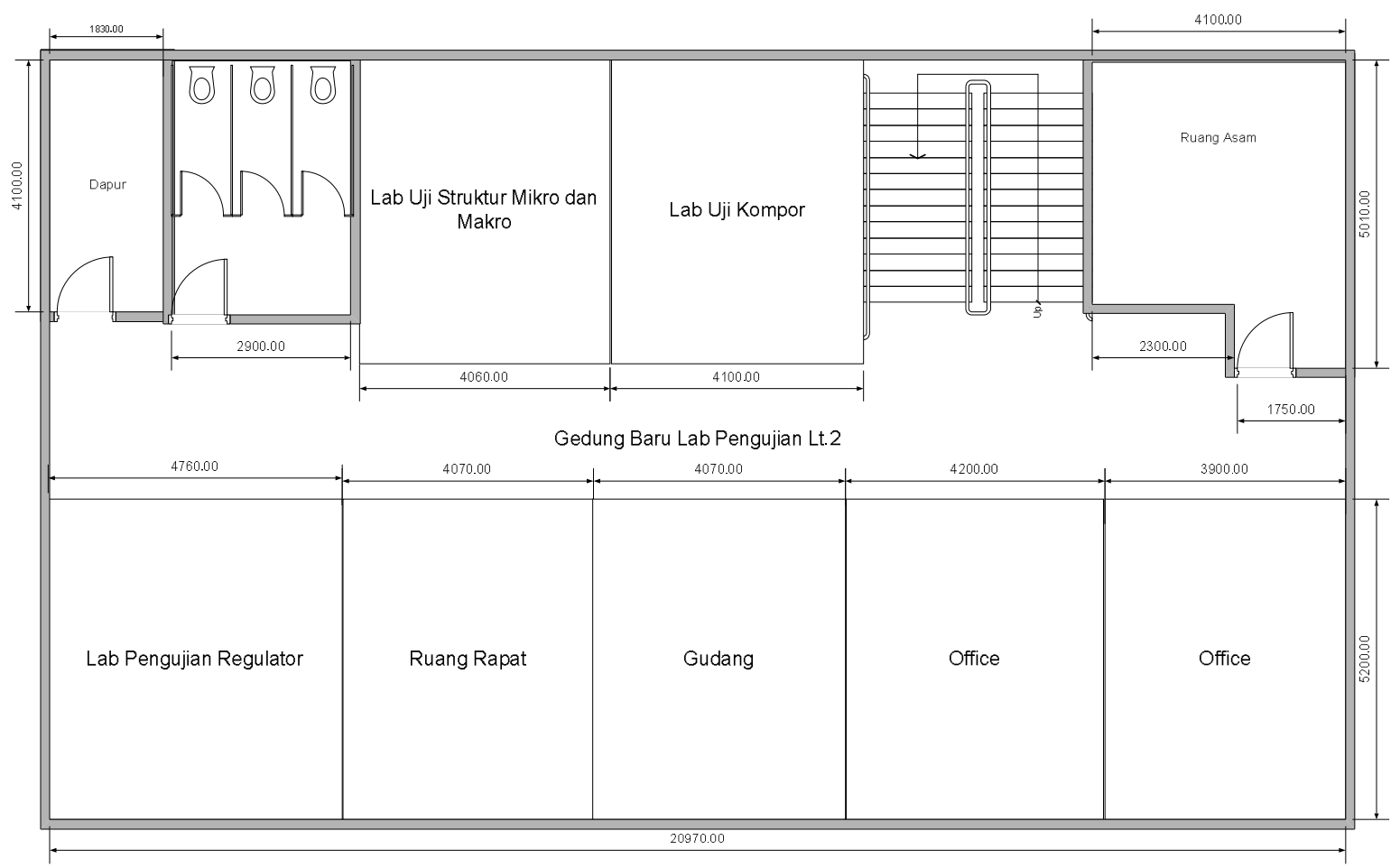

Gambar 4. Layout awal laboratorium pengujian baru lt.2 


\section{Perhitungan Luas Lantai}

Fasilitas/mesin

pengujian di

laboratorium pengujian terbagi ke dalam dua yaitu berdasarkan product layout dan process layout.Mesin yang termasuk ke dalam product layout adalah mesin uji yang hanya digunakan untuk 1 lingkup produk. Sedangkan mesin yang termasuk ke dalam proses layout adalah mesin uji yang digunakan untuk beberapa lingkup produk tetapi memiliki fungsi yang sama. Berikut adalah hasil identifikasi mesin uji berdasarkan product layout dan process layout beserta perhitungan kebutuhan luas lantai:

Tabel 2. Luas lantai fasilitas pengujian sepeda

\begin{tabular}{|c|c|c|c|c|c|c|c|c|c|}
\hline \multirow[t]{2}{*}{ No } & \multirow[t]{2}{*}{$\begin{array}{c}\text { Nama Stasiun } \\
\text { Kerja }\end{array}$} & \multirow[t]{2}{*}{ Nama mesin } & \multicolumn{2}{|c|}{$\begin{array}{c}\text { Dimensi } \\
\text { Mesin (m) }\end{array}$} & \multicolumn{2}{|c|}{$\begin{array}{l}\text { Dimensi } \\
\text { operator } \\
(\mathrm{m})\end{array}$} & \multirow{2}{*}{$\begin{array}{c}\text { Luas } \\
\text { total } \\
(\mathrm{m})\end{array}$} & \multirow[t]{2}{*}{$\begin{array}{c}\text { Kelonggar } \\
\text { an }\end{array}$} & \multirow{2}{*}{$\begin{array}{c}\text { Luas } \\
\text { total } \\
\text { akhir } \\
(\mathrm{m})\end{array}$} \\
\hline & & & $\mathrm{P}$ & $\mathrm{L}$ & $\mathrm{P}$ & $\mathrm{L}$ & & & \\
\hline \multirow[t]{2}{*}{1} & \multirow[t]{2}{*}{$\begin{array}{l}\text { Alat uji lelah } \\
\text { rangka }\end{array}$} & $\begin{array}{l}\text { CY6715 (alat uji } \\
\text { lelah rangka)+ } \\
\text { controller }\end{array}$ & 3 & 1 & 3 & 1 & 6 & 6 & 12 \\
\hline & & Lemari & 1 & 1 & & & 1 & & 1 \\
\hline \multirow[t]{2}{*}{2} & \multirow{2}{*}{$\begin{array}{l}\text { Alat uji impak } \\
\text { rangka }\end{array}$} & $\begin{array}{l}\text { Alat uji impak } \\
\text { rangka+ controller }\end{array}$ & 1.8 & 1.4 & 1.8 & 1 & 4.32 & 4.32 & 8.64 \\
\hline & & Lemari & 1 & 1 & & & 1 & & 1 \\
\hline \multirow{5}{*}{3} & \multirow{5}{*}{ CY 6751} & Mesin CY6751 & 3.6 & 2.4 & 3.6 & 1 & 12.24 & 12.24 & 24.48 \\
\hline & & box oil & 1.3 & 1.3 & & & 1.69 & 1.69 & 3.38 \\
\hline & & oil coolant & 1.6 & 0.8 & & & 1.28 & 1.28 & 2.56 \\
\hline & & Gardu & 1 & 1 & & & 1 & & 1 \\
\hline & & Lemari & 1 & 1 & & & 1 & & 1 \\
\hline \multirow[t]{2}{*}{4} & \multirow{2}{*}{$\begin{array}{l}\text { Alat uji } \\
\text { struktur dan } \\
\text { rem }\end{array}$} & $\begin{array}{l}\text { CY } \\
6768+\text { kompressor }\end{array}$ & 3.7 & 2 & 3.7 & 2 & 14.8 & 14.8 & 29.6 \\
\hline & & Contoroller & 1 & 1 & & & 1 & & 1 \\
\hline 5 & $\begin{array}{l}\text { Ruang } \\
\text { preparasi, uji } \\
\text { dimensi }\end{array}$ & $\begin{array}{l}\text { Ruang preparasi dan } \\
\text { uji dimensi }\end{array}$ & 4 & 6 & & & 24 & & 24 \\
\hline
\end{tabular}

Tabel 1. Luas lantai fasilitas pengujian regulator

\begin{tabular}{|c|c|c|c|c|c|c|c|c|c|}
\hline \multirow[t]{2}{*}{ No } & \multirow[t]{2}{*}{$\begin{array}{c}\text { Nama Stasiun } \\
\text { Kerja }\end{array}$} & \multirow[t]{2}{*}{ Nama mesin } & \multicolumn{2}{|c|}{$\begin{array}{c}\text { Dimensi } \\
\text { Mesin } \\
(\mathrm{m})\end{array}$} & \multicolumn{2}{|c|}{$\begin{array}{c}\text { Dimensi } \\
\text { operator } \\
(\mathrm{m})\end{array}$} & \multirow{2}{*}{$\begin{array}{l}\text { Luas } \\
\text { total } \\
(\mathrm{m})\end{array}$} & \multirow[t]{2}{*}{$\begin{array}{l}\text { Kelongg } \\
\text { aran }\end{array}$} & \multirow{2}{*}{$\begin{array}{c}\text { Luas } \\
\text { total } \\
\text { akhir } \\
(\mathrm{m})\end{array}$} \\
\hline & & & $\mathrm{P}$ & $\mathrm{L}$ & $\mathrm{P}$ & $\mathrm{L}$ & & & \\
\hline 1 & $\begin{array}{l}\text { Alat Uji } \\
\text { Ketahanan } \\
\text { Pemantik } \\
\text { regulator }\end{array}$ & $\begin{array}{l}\text { Alat Uji Ketahanan } \\
\text { Pemantik regulator }\end{array}$ & 1 & 0.5 & 1 & 0.5 & 1 & 1.5 & 2.5 \\
\hline 2 & $\begin{array}{l}\text { Alat uji regulator } \\
\text { high pressure }\end{array}$ & $\begin{array}{l}\text { Alat uji regulator } \\
\text { high pressure }\end{array}$ & 1.5 & 0.8 & 1.5 & 0.5 & 1.95 & 2.925 & 4.875 \\
\hline 3 & Alat ukur tekanan & Alat ukur tekanan & 1 & 0.5 & 1 & 0.5 & 1 & 1.5 & 2.5 \\
\hline 4 & Alat uji ketahanan & Alat uji ketahanan & 0.5 & 0.5 & 0.5 & 0.5 & 0.5 & 0.75 & 1.25 \\
\hline 5 & Kompressor & Kompressor & 1 & 1 & & & 1 & & 1 \\
\hline
\end{tabular}


Tabel 2. Luas lantai fasilitas pengujian kompor

\begin{tabular}{|c|c|c|c|c|c|c|c|c|c|}
\hline \multirow[t]{2}{*}{ No } & \multirow[t]{2}{*}{$\begin{array}{c}\text { Nama Stasiun } \\
\text { Kerja }\end{array}$} & \multirow[t]{2}{*}{ Nama mesin } & \multicolumn{2}{|c|}{$\begin{array}{c}\text { Dimensi } \\
\text { Mesin } \\
(\mathrm{m})\end{array}$} & \multicolumn{2}{|c|}{$\begin{array}{c}\text { Dimensi } \\
\text { operator } \\
(\mathrm{m})\end{array}$} & \multirow{2}{*}{$\begin{array}{c}\text { Luas } \\
\text { total } \\
(\mathrm{m})\end{array}$} & \multirow[t]{2}{*}{$\begin{array}{c}\text { Kelongga } \\
\text { ran }\end{array}$} & \multirow{2}{*}{$\begin{array}{c}\text { Luas } \\
\text { total } \\
\text { akhir } \\
(\mathrm{m})\end{array}$} \\
\hline & & & $\mathrm{P}$ & $\mathrm{L}$ & $\mathrm{P}$ & $\mathrm{L}$ & & & \\
\hline 1 & Alat uji pemantik & Alat uji pemantik & 1 & 1 & 1 & 0.5 & 1.5 & 1.5 & 3 \\
\hline 2 & Alat uji kebocoran & Alat uji kebocoran & 1.5 & 0.5 & 1.5 & 0.5 & 1.5 & 1.5 & 3 \\
\hline 3 & Meja uji & Meja uji & 3.9 & 0.8 & 3.9 & 0.5 & 5.07 & 5.07 & 10.14 \\
\hline 4 & $\begin{array}{l}\text { Meja gambar } \\
\text { miring }\end{array}$ & $\begin{array}{l}\text { Meja gambar } \\
\text { miring }\end{array}$ & 1.5 & 1.5 & 1.5 & 0.5 & 3 & 3 & 6 \\
\hline 5 & Alat uji jatuh & Alat uji jatuh & 1 & 0.5 & 1 & 0.5 & 1 & 1 & 2 \\
\hline 6 & Lemari & Lemari & 0.5 & 0.5 & & & 0.25 & & 0.25 \\
\hline
\end{tabular}

Tabel 3. Luas lantai fasilitas preparasi sampel uji

\begin{tabular}{|c|c|c|c|c|c|c|c|c|c|}
\hline \multirow[t]{2}{*}{ No } & \multirow[t]{2}{*}{ Nama Stasiun Kerja } & \multirow[t]{2}{*}{ Nama mesin } & \multicolumn{2}{|c|}{$\begin{array}{l}\text { Dimensi } \\
\text { Mesin } \\
(\mathrm{m})\end{array}$} & \multicolumn{2}{|c|}{$\begin{array}{c}\text { Dimensi } \\
\text { operator } \\
(\mathrm{m})\end{array}$} & \multirow[t]{2}{*}{$\begin{array}{l}\text { Luas } \\
\text { total } \\
(\mathrm{m})\end{array}$} & \multirow[t]{2}{*}{$\begin{array}{c}\text { Kelongga } \\
\text { ran }\end{array}$} & \multirow{2}{*}{$\begin{array}{c}\text { Luas } \\
\text { total } \\
\text { akhir } \\
(\mathrm{m})\end{array}$} \\
\hline & & & $\mathrm{P}$ & $\mathrm{L}$ & $\mathrm{P}$ & $\mathrm{L}$ & & & \\
\hline 1 & Mesin bubut & Mesin bubut & 2 & 0.8 & 2 & 0.5 & 2.6 & 3.9 & 6.5 \\
\hline 2 & $\begin{array}{l}\text { Grinding untuk } \\
\text { spektro dan } \\
\text { hardness }\end{array}$ & $\begin{array}{l}\text { Grinding untuk } \\
\text { spektro dan } \\
\text { hardness }\end{array}$ & 0.6 & 0.6 & 0.6 & 0.5 & 0.66 & 0.99 & 1.65 \\
\hline 3 & Mesin gergaji logam & $\begin{array}{l}\text { Mesin gergaji } \\
\text { logam }\end{array}$ & 0.4 & 1 & 0.4 & 0.5 & 0.6 & 0.9 & 1.5 \\
\hline 4 & $\begin{array}{l}\text { Mesin freis dan } \\
\text { ragum }\end{array}$ & $\begin{array}{l}\text { Mesin freis dan } \\
\text { ragum }\end{array}$ & 2 & 1.5 & 2 & 0.5 & 4 & 6 & 10 \\
\hline
\end{tabular}

Tabel 4. Luas lantai fasilitas pengujian spektrometer

\begin{tabular}{|c|c|c|c|c|c|c|c|c|c|}
\hline \multirow[t]{2}{*}{ No } & \multirow[t]{2}{*}{ Nama Stasiun Kerja } & \multirow[t]{2}{*}{ Nama mesin } & \multicolumn{2}{|c|}{$\begin{array}{l}\text { Dimensi } \\
\text { Mesin } \\
(\mathrm{m})\end{array}$} & \multicolumn{2}{|c|}{$\begin{array}{l}\text { Dimensi } \\
\text { operator } \\
(\mathrm{m})\end{array}$} & \multirow[t]{2}{*}{$\begin{array}{l}\text { Luas } \\
\text { total } \\
(\mathrm{m})\end{array}$} & \multirow[t]{2}{*}{$\begin{array}{l}\text { Kelongga } \\
\text { ran } \\
(150 \%)\end{array}$} & \multirow{2}{*}{$\begin{array}{c}\text { Luas } \\
\text { total } \\
\text { akhir } \\
\text { (m) }\end{array}$} \\
\hline & & & $\mathrm{P}$ & $\mathrm{L}$ & $\mathrm{P}$ & $\mathrm{L}$ & & & \\
\hline 1 & Spektro archmet & Spektro archmet & 1 & 1 & 1 & 0.5 & 1.5 & 2.25 & 3.75 \\
\hline 2 & Spektro Metalscan & $\begin{array}{l}\text { Spektro } \\
\text { Metalscan+kompu } \\
\text { ter }\end{array}$ & 1.5 & 1 & 1.5 & 0.5 & 2.25 & 3.375 & 5.625 \\
\hline 3 & $\begin{array}{l}\text { Spectro PMI } \\
\text { MasterPro }\end{array}$ & $\begin{array}{l}\text { Spectro PMI } \\
\text { MasterPro }\end{array}$ & 1 & 1 & 1 & 0.5 & 1.5 & 2.25 & 3.75 \\
\hline 4 & $\begin{array}{l}\text { Spectro Foundry } \\
\text { Master }\end{array}$ & $\begin{array}{l}\text { Spectro Foundry } \\
\text { Master+komputer }\end{array}$ & 2 & 1 & 2 & 0.5 & 3 & 4.5 & 7.5 \\
\hline 5 & Tool spektro & Tool spektro & 1 & 1 & 0 & 0 & 1 & & 1 \\
\hline 6 & Meja tulis & Meja tulis & 2 & 1 & 0 & 0 & 2 & & 2 \\
\hline 7 & Tempat gas & Tempat gas & 2 & 1 & 0 & 0 & 2 & & 2 \\
\hline
\end{tabular}

Tabel 5. Luas lantai fasilitas pengujian UTM 


\begin{tabular}{|c|c|c|c|c|c|c|c|c|c|}
\hline \multirow[t]{2}{*}{ No } & \multirow[t]{2}{*}{$\begin{array}{c}\text { Nama Stasiun } \\
\text { Kerja }\end{array}$} & \multirow[t]{2}{*}{ Nama mesin } & \multicolumn{2}{|c|}{$\begin{array}{c}\text { Dimensi } \\
\text { Mesin (m) }\end{array}$} & \multicolumn{2}{|c|}{$\begin{array}{c}\text { Dimensi } \\
\text { operator } \\
(\mathrm{m})\end{array}$} & \multirow[t]{2}{*}{$\begin{array}{c}\text { Luas } \\
\text { total } \\
(\mathrm{m})\end{array}$} & \multirow{2}{*}{$\begin{array}{c}\text { Kelongg } \\
\text { aran } \\
(100 \%)\end{array}$} & \multirow{2}{*}{$\begin{array}{c}\text { Luas } \\
\text { total } \\
\text { akhir } \\
(\mathrm{m})\end{array}$} \\
\hline & & & $\mathrm{P}$ & $\mathrm{L}$ & $\mathrm{P}$ & $\mathrm{L}$ & & & \\
\hline 1 & $\begin{array}{l}\text { Alat uji tarik } \\
\text { MFL }\end{array}$ & Alat uji tarik MFL & 2.6 & 1 & 2.6 & 0.5 & 3.9 & 3.9 & 7.8 \\
\hline 2 & $\begin{array}{l}\text { Alat uji tarik } \\
\text { Lloyd }\end{array}$ & $\begin{array}{l}\text { Alat uji tarik } \\
\text { Lloyd }\end{array}$ & 2 & 0.7 & 2 & 0.5 & 2.4 & 2.4 & 4.8 \\
\hline 3 & $\begin{array}{l}\text { Alat uji tarik } \\
\text { Dartek }\end{array}$ & $\begin{array}{l}\text { Alat uji tarik } \\
\text { Dartek }\end{array}$ & 3.2 & 4.5 & 3.2 & 0.5 & 16 & 16 & 32 \\
\hline 4 & $\begin{array}{l}\text { Alat uji tarik } \\
\text { Hungsta }\end{array}$ & $\begin{array}{l}\text { Alat uji tarik } \\
\text { Hungsta }\end{array}$ & 3 & 1.3 & 3 & 0.5 & 5.4 & 5.4 & 10.8 \\
\hline 5 & Creep & Creep & 1.7 & 0.8 & 1.7 & 0.5 & 2.21 & 2.21 & 4.42 \\
\hline
\end{tabular}

Tabel 6. Luas lantai fasilitas pengujian struktur mikro dan makro

\begin{tabular}{|c|c|c|c|c|c|c|c|c|c|}
\hline \multirow[t]{2}{*}{ No } & \multirow{2}{*}{$\begin{array}{c}\text { Nama Stasiun } \\
\text { Kerja }\end{array}$} & \multirow[t]{2}{*}{ Nama mesin } & \multicolumn{2}{|c|}{$\begin{array}{l}\text { Dimensi } \\
\text { Mesin (m) }\end{array}$} & \multicolumn{2}{|c|}{$\begin{array}{c}\text { Dimensi } \\
\text { operator } \\
(\mathrm{m})\end{array}$} & \multirow{2}{*}{$\begin{array}{l}\text { Luas } \\
\text { total } \\
(\mathrm{m})\end{array}$} & \multirow{2}{*}{$\begin{array}{l}\text { Kelongg } \\
\text { aran } \\
(150 \%)\end{array}$} & \multirow{2}{*}{$\begin{array}{c}\text { Luas } \\
\text { total } \\
\text { akhir } \\
(\mathrm{m})\end{array}$} \\
\hline & & & $\mathrm{P}$ & $\mathrm{L}$ & $\mathrm{P}$ & $\mathrm{L}$ & & & \\
\hline 1 & Clemex Meiji & Clemex Meiji & 1.6 & 0.8 & 1.6 & 0.5 & 2.08 & 2.08 & 4.16 \\
\hline 2 & $\begin{array}{l}\text { Uji keras mikro } \\
\text { Vickers }\end{array}$ & $\begin{array}{l}\text { Uji keras mikro } \\
\text { vickers }\end{array}$ & 0.5 & 0.8 & 0.5 & 0.5 & 0.65 & 0.65 & 1.3 \\
\hline 3 & $\begin{array}{l}\text { Microsoft } \\
\text { metalurgi nikon }\end{array}$ & $\begin{array}{l}\text { Microsoft } \\
\text { metalurgi Nikon }\end{array}$ & 0.8 & 0.8 & 0.8 & 0.5 & 1.04 & 1.04 & 2.08 \\
\hline 4 & $\begin{array}{l}\text { Preparasi mikro } \\
\text { struktur }\end{array}$ & $\begin{array}{l}\text { Reparasi mikro } \\
\text { struktur }\end{array}$ & 4 & 0.8 & 4 & 0.5 & 5.2 & 5.2 & 10.4 \\
\hline 5 & $\begin{array}{l}\text { Alat } \\
\text { penyimpanan }\end{array}$ & Alat penyimpanan & 2.4 & 0.5 & 0 & 0 & 1.2 & & 1.2 \\
\hline 6 & $\begin{array}{l}\text { Meja kerja dan } \\
\text { lemari }\end{array}$ & $\begin{array}{l}\text { Meja kerja dan } \\
\text { lemari }\end{array}$ & 2 & 1.2 & 0 & 0 & 2.4 & & 2.4 \\
\hline
\end{tabular}

Tabel 7 Luas lantai fasilitas pengujian kekerasan

\begin{tabular}{|c|c|c|c|c|c|c|c|c|c|}
\hline \multirow[t]{2}{*}{ No } & \multirow[t]{2}{*}{$\begin{array}{c}\text { Nama Stasiun } \\
\text { Kerja }\end{array}$} & \multirow[t]{2}{*}{ Nama mesin } & \multicolumn{2}{|c|}{$\begin{array}{l}\text { Dimensi } \\
\text { Mesin (m) }\end{array}$} & \multicolumn{2}{|c|}{$\begin{array}{l}\text { Dimensi } \\
\text { operator } \\
(\mathrm{m})\end{array}$} & \multirow{2}{*}{$\begin{array}{c}\text { Luas } \\
\text { total } \\
(\mathrm{m})\end{array}$} & \multirow{2}{*}{$\begin{array}{c}\text { Kelon } \\
\text { ggaran } \\
(150 \% \\
)\end{array}$} & \multirow{2}{*}{$\begin{array}{c}\text { Luas } \\
\text { total } \\
\text { akhir } \\
(\mathrm{m})\end{array}$} \\
\hline & & & $\mathrm{P}$ & $\mathrm{L}$ & $\mathrm{P}$ & $\mathrm{L}$ & & & \\
\hline 1 & $\begin{array}{l}\text { Vickers hardness } \\
\text { tester INDENTEC }\end{array}$ & $\begin{array}{l}\text { Vickers hardness } \\
\text { tester } \\
\text { INDENTEC }\end{array}$ & 0.4 & 0.8 & 0.4 & 0.5 & 0.52 & 0.78 & 1.3 \\
\hline 2 & $\begin{array}{l}\text { Rockwell Brinell } \\
\text { hardnes tester } \\
\text { AFFRI }\end{array}$ & $\begin{array}{l}\text { Rockwell Brinell } \\
\text { hardnes tester } \\
\text { AFFRI }\end{array}$ & 0.4 & 0.8 & 0.4 & 0.5 & 0.52 & 0.78 & 1.3 \\
\hline 3 & $\begin{array}{l}\text { Surface roughness } \\
\text { measuring test }\end{array}$ & $\begin{array}{l}\text { Surface } \\
\text { roughness } \\
\text { measuring test }\end{array}$ & 0.8 & 0.6 & 0.8 & 0.5 & 0.88 & 1.32 & 2.2 \\
\hline 4 & $\begin{array}{l}\text { Dunometer } \\
\text { Brinnell } \\
\text { HOYTOM }\end{array}$ & $\begin{array}{l}\text { Dunometer } \\
\text { Brinnell } \\
\text { HOYTOM }\end{array}$ & 0.4 & 0.8 & 0.4 & 0.5 & 0.52 & 0.78 & 1.3 \\
\hline 5 & $\begin{array}{l}\text { Rockwell hardness } \\
\text { tester TORSEE }\end{array}$ & $\begin{array}{l}\text { Rockwell } \\
\text { hardness tester } \\
\text { TORSEE }\end{array}$ & 0.4 & 0.8 & 0.4 & 0.5 & 0.52 & 0.78 & 1.3 \\
\hline
\end{tabular}




\begin{tabular}{|c|l|l|c|c|c|c|c|c|c|}
6 & $\begin{array}{l}\text { Dunometer } \\
\text { Brinnell Rockwell } \\
\text { HOYTOM }\end{array}$ & $\begin{array}{l}\text { Dunometer } \\
\text { Brinnell Rockwell } \\
\text { HOYTOM }\end{array}$ & 0.4 & 0.8 & 0.4 & 0.5 & 0.52 & 0.78 & 1.3 \\
\hline & $\begin{array}{l}\text { Brinell hardness } \\
\text { tester HOYTOM }\end{array}$ & $\begin{array}{l}\text { Brinell hardness } \\
\text { tester HOYTOM } \\
\text { MINOR }\end{array}$ & 0.4 & 0.8 & 0.4 & 0.5 & 0.52 & 0.78 & 1.3 \\
\hline 8 & Shore scale & Shore scale & 0.2 & 0.5 & 0.5 & 0.5 & 0.35 & 0.525 & 0.875 \\
\hline
\end{tabular}

Tabel 8. Luas lantai fasilitas pengujian impak

\begin{tabular}{|c|c|c|c|c|c|c|c|c|c|}
\hline \multirow[t]{2}{*}{ No } & \multirow[t]{2}{*}{$\begin{array}{c}\text { Nama Stasiun } \\
\text { Kerja }\end{array}$} & \multirow[t]{2}{*}{ Nama mesin } & \multicolumn{2}{|c|}{$\begin{array}{l}\text { Dimensi } \\
\text { Mesin (m) }\end{array}$} & \multicolumn{2}{|c|}{$\begin{array}{c}\text { Dimensi } \\
\text { operator } \\
(\mathrm{m})\end{array}$} & \multirow[t]{2}{*}{$\begin{array}{l}\text { Luas } \\
\text { total } \\
(\mathrm{m})\end{array}$} & \multirow[t]{2}{*}{$\begin{array}{l}\text { Kelong } \\
\text { garan }\end{array}$} & \multirow{2}{*}{$\begin{array}{c}\text { Luas } \\
\text { total } \\
\text { akhir } \\
\text { (m) }\end{array}$} \\
\hline & & & $\mathrm{P}$ & $\mathrm{L}$ & $P$ & $\mathrm{~L}$ & & & \\
\hline 1 & Alat Uji Impak & $\begin{array}{l}\text { Alat uji impak } \\
\text { charpy merk } \\
\text { MFL }\end{array}$ & 1 & 1 & 1 & 0.5 & 1.5 & 2.25 & 3.75 \\
\hline \multirow[t]{2}{*}{2} & \multirow{2}{*}{$\begin{array}{l}\text { Impak hungta } 30 \\
\mathrm{kgm}\end{array}$} & $\begin{array}{l}\text { Impak hungta } 30 \\
\text { kgm }\end{array}$ & 1.6 & 0.6 & 1.6 & 0.5 & \multirow[t]{2}{*}{2.01} & \multirow[t]{2}{*}{3.015} & \multirow[t]{2}{*}{5.025} \\
\hline & & Controller & 0.5 & 0.5 & & & & & \\
\hline 3 & Black charpy & Black charpy & 0.5 & 0.5 & 0.5 & 0.5 & 0.5 & 0.75 & 1.25 \\
\hline
\end{tabular}

Tabel 9. Luas lantai fasilitas pengujian lainnya

\begin{tabular}{|c|c|c|c|c|c|c|c|c|c|}
\hline \multirow[t]{2}{*}{ No } & \multirow[t]{2}{*}{$\begin{array}{c}\text { Nama } \\
\text { Stasiun Kerja }\end{array}$} & \multirow[t]{2}{*}{ Nama mesin } & \multicolumn{2}{|c|}{$\begin{array}{c}\text { Dimensi } \\
\text { Mesin (m) }\end{array}$} & \multicolumn{2}{|c|}{$\begin{array}{l}\text { Dimensi } \\
\text { operator } \\
\text { (m) }\end{array}$} & \multirow{2}{*}{$\begin{array}{l}\text { Luas } \\
\text { total } \\
(\mathrm{m})\end{array}$} & \multirow[t]{2}{*}{$\begin{array}{l}\text { Kelong } \\
\text { garan }\end{array}$} & \multirow{2}{*}{$\begin{array}{l}\text { Luas } \\
\text { total } \\
\text { akhir } \\
(\mathrm{m})\end{array}$} \\
\hline & & & $\mathrm{P}$ & $\mathrm{L}$ & $\mathrm{P}$ & $\mathrm{L}$ & & & \\
\hline 1 & $\begin{array}{l}\text { Uji kedap } \\
\text { udara }\end{array}$ & Uji kedap udara & 1.3 & 1 & 1.3 & 0.5 & 1.95 & 2.925 & 4.875 \\
\hline 2 & Timbangan & balance Sartorius & 0.5 & 0.5 & 0.5 & 0.5 & 0.5 & 0.75 & 1.25 \\
\hline 3 & $\begin{array}{l}\text { Oven } \\
\text { Memmert }\end{array}$ & Oven Memmert & 0.5 & 0.5 & 0.5 & 0.5 & 0.5 & 0.75 & 1.25 \\
\hline 5 & $\begin{array}{l}\text { Bursting/Hydro } \\
\text { test product }\end{array}$ & $\begin{array}{l}\text { Bursting/Hydro test } \\
\text { product }\end{array}$ & 4.5 & 4 & 4.5 & 0.5 & 20.25 & 30.375 & 50.625 \\
\hline 6 & Timbangan & timbangan lucky & 1 & 0.5 & 1 & 0.5 & 1 & 1.5 & 2.5 \\
\hline 7 & Meja & Meja & 1 & 0.5 & 1 & 0.5 & 1 & 1 & 2 \\
\hline \multirow{2}{*}{8} & \multirow{2}{*}{$\begin{array}{l}\text { Alat uji } \\
\text { ketahanan } \\
\text { katup }\end{array}$} & Alat uji ketahanan & 0.5 & 0.5 & 0.5 & 0.5 & 0.5 & 0.75 & 1.25 \\
\hline & & Kompressor & 1 & 1 & & & 1 & & 1 \\
\hline 9 & $\begin{array}{l}\text { Alat uji } \\
\text { hydrostatis }\end{array}$ & $\begin{array}{l}\text { Alat uji hydrostatis } \\
\text { Kyowa }\end{array}$ & 0.5 & 0.5 & 0.5 & 0.5 & 0.5 & 0.75 & 1.25 \\
\hline 10 & $\begin{array}{l}\text { Alat uji } \\
\text { relaksasi utk } \\
\text { kawat tali baja }\end{array}$ & $\begin{array}{l}\text { Alat uji relaksasi } \\
\text { utk kawat tali baja }\end{array}$ & 3.6 & 2.6 & 3.6 & 0.5 & 11.16 & 11.16 & 22.32 \\
\hline 11 & $\begin{array}{l}\text { Alat uji puntir } \\
\text { utk kawat/tali } \\
\text { kawat }\end{array}$ & $\begin{array}{l}\text { Alat uji puntir utk } \\
\text { kawat/tali kawat }\end{array}$ & 2.4 & 0.7 & 2.4 & 0.5 & 2.88 & 4.32 & 7.2 \\
\hline 12 & $\begin{array}{l}\text { Dynamic } \\
\text { torque tester }\end{array}$ & $\begin{array}{l}\text { Dynamic torque } \\
\text { tester }\end{array}$ & 1.5 & 0.7 & 1.5 & 0.5 & 1.8 & 2.7 & 4.5 \\
\hline 13 & Ruang asam & Ruang asam & 4 & 5 & & & 20 & 30 & 50 \\
\hline 14 & Ball joint & Ball joint & 2.5 & 1 & 2.5 & 0.5 & 4.75 & 4.75 & 9.5 \\
\hline
\end{tabular}




\begin{tabular}{|l|l|l|c|c|c|c|c|c|c|} 
& & Controller & 1 & 1 & & & & & \\
\hline 15 & Cross joint & Cross joint & 4.5 & 1 & 4.5 & 0.5 & 6.75 & 6.75 & 13.5 \\
\hline
\end{tabular}

Berdasarkan perhitungan luas lantai, total luas lantai yang dibutuhkan sebesar $351,97 \mathrm{~m}^{2}$. Sedangkan luas laboratorium pengujian yang akan dirancang ulang seluas $708 \mathrm{~m}^{2}$ sehingga tidak diperlukan penambahan lahan.

Penyusunan ARC (Activity Relationship Chart) Dari seluruh fasilitas pengujian yang dibutuhkan kemudian dianalisa tingkat hubungan keterkaitannya dengan fasilitas lain dengan melakukan wawancara dan diskusi dengan operator pengujian. Dari hasil wawancara dan diskusi kemudian dibuat ARC (Activity Relationship Chart) yang dirangkum menjadi lembar kerja keterkaitan kegiatan seperti pada Tabel di bawah ini dimana untuk tingkat hubungan A akan menjadi prioritas ke-1, E prioritas ke-2, I prioritas ke-3, O prioritas ke-4, $\mathrm{U}$ prioritas

ke-5.

Tabel 10. Lembar kerja keterkaitan kegiatan

\begin{tabular}{|c|c|c|c|c|c|c|c|}
\hline \multirow[t]{2}{*}{ No } & \multirow[t]{2}{*}{ Pusat kegiatan } & \multicolumn{6}{|c|}{ Tingkat Hubungan } \\
\hline & & A & $\mathrm{E}$ & $\mathrm{I}$ & $\mathrm{O}$ & $\mathrm{U}$ & $\mathrm{X}$ \\
\hline 1 & Lab uji sepeda & & & & & $2-25$ & \\
\hline 2 & Lab uji regulator & 11 & & $7,10,12,13,15$ & 8,9 & $1-7,14,16-25$ & \\
\hline 3 & Lab uji kompor & & & & & $1-2,4-25$ & \\
\hline 4 & $\begin{array}{l}\text { Lab uji meteran } \\
\text { air }\end{array}$ & & 7 & 14,25 & & $1-3,5,6,8-13,15-24,26$ & \\
\hline 5 & $\begin{array}{l}\text { Alat uji } \\
\text { ketahanan katup }\end{array}$ & & & 7 & $11,14,15$ & $1-6,8-10,12,13,16-26$ & \\
\hline 6 & Meja "rata" & & & & & $1-5,7-26$ & \\
\hline 7 & Lab spektrometer & & 4 & $2,5,8,10,11,15$ & $9,12,14,17$ & $1,3,6,13,16,18-25$ & \\
\hline 8 & Lab uji UTM & & & $7,10,12,25$ & & $1-6,9,11,13-24,26$ & \\
\hline 9 & $\begin{array}{l}\text { Lab uji struktur } \\
\text { mikro dan makro }\end{array}$ & & 10 & 22 & $2,7,12$ & $1-8,11,13-21,23-25$ & \\
\hline 10 & Lab uji kekerasan & & 9 & $2,7,8,12,25$ & 13,15 , & $1-6,11,14,16-24,26$ & \\
\hline 11 & $\begin{array}{l}\text { Alat uji kedap } \\
\text { udara }\end{array}$ & 2 & & 7 & 5 & $1,3,4,6,8-10,12-25$ & \\
\hline 12 & Alat uji impak & & & $2,8,10,25$ & 7,9 & $1,3-6,11-24$ & \\
\hline 13 & Balance & & & 2,15 & 10 & $1,3-9,11-14,16-25$ & \\
\hline 14 & $\begin{array}{l}\text { Alat uji } \\
\text { hydrostatis } \\
\text { Kyowa }\end{array}$ & & 21 & 4,17 & 5,7 & $1-3,6,8-16,18-20,22-25$ & \\
\hline 15 & Oven memmert & & & $2,7,13$ & 5,10 & $1,3,4,6,8,9,11,12,14-25$ & \\
\hline 16 & $X$ ray $N D T$ & & & & & $1-15,17-25$ & \\
\hline 17 & $\begin{array}{l}\text { Bursting Hydro } \\
\text { test }\end{array}$ & & & 14 & 7 & $1-6,8-13,15,16,18-25$ & \\
\hline 18 & $\begin{array}{l}\text { Alat uji relaksasi } \\
\text { utk kawat tali } \\
\text { baja }\end{array}$ & & & 25 & 19,20 & $1-17,21-24,25$ & \\
\hline 19 & $\begin{array}{l}\text { Alat uji puntir utk } \\
\text { kawat/tali kawat }\end{array}$ & & & 25 & 18,20 & $1-17,21-24,25$ & \\
\hline 20 & $\begin{array}{l}\text { Dynamic torque } \\
\text { tester }\end{array}$ & & & 25 & 18,19 & $1-17,21-24,25$ & \\
\hline 21 & Timbangan Lucky & & 14 & & & $1-13,15-20,22-25$ & \\
\hline 22 & Ruang asam & & & 9 & & $1-8,10-21,23-25$ & \\
\hline 23 & Ball joint & & & & 24 & $1-22,25$ & \\
\hline 24 & Cross joint & & & & 23 & $1-22,25$ & \\
\hline 25 & Preparasi sampel & & & $4,8,10,12,18,19,20$ & & $1-3,5-7,9,11,13-17,21-$ & \\
\hline
\end{tabular}


Faktor-faktor yang menentukan keterkaitan kegiatan antara lain urutan aliran pekerjaan, mempergunakan peralatan yang sama, menggunakan catatan yang sama, menggunakan ruangan yang sama, memudahkan pemindahan bahan, dan bising/kotor/debu/getaran. Dari lembar kerja keterkaitan kegiatan selanjutnya dapat diperoleh Activity Relationship Diagram
(ARD) yang merupakan diagram balok yang menunjukkan pendekatan keterkaitan kegiatan. Fasilitas disusun berdasarkan tingkat keterkaitannya. Fasilitas yang tingkat keterkaitannya tinggi maka akan didekatkan. Berdasarkan perhitungan dihasilkan ARD diagram untuk kegiatan di laboratorium pengujian, sebagai berikut

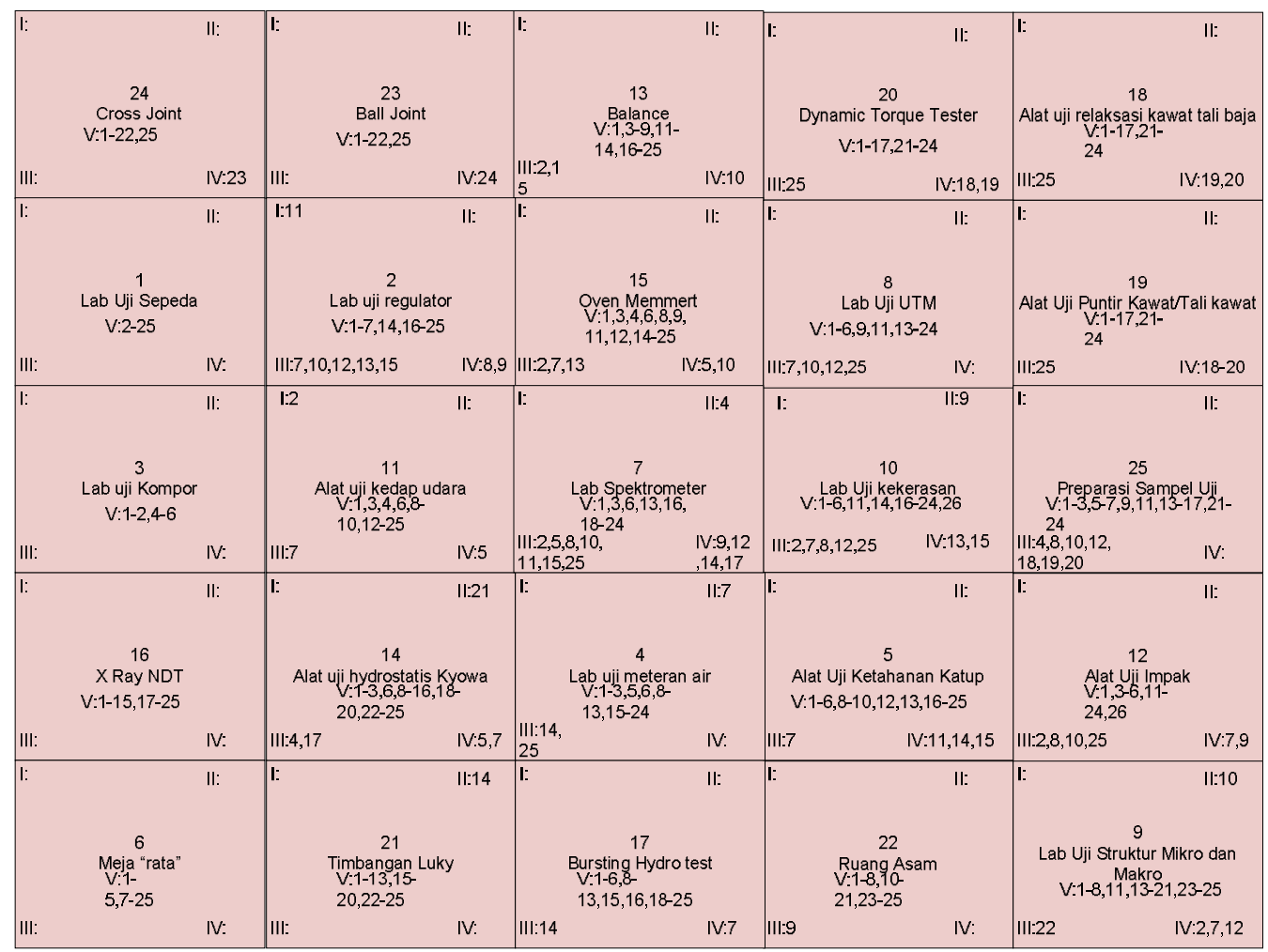

Gambar 5. Activity relationship diagram laboratorium pengujian

Hasil ARD yang telah disusun menjadi dasar perancangan ulang dapat dilihat pada gambar dalam pembuatan template laboratorium 6,7 , dan 8 . pengujian yang disesuaikan dengan kondisi bangunan laboratorium yang ada.Berdasarkan ARD diperoleh template layout laboratorium pengujian lama yang terdiri dari ruang preparasi sampel, mesin/alat uji UTM, mesin/alat uji kekerasan, mesin/alat uji impak, mesin/alat uji spectrometer, mesin/alat uji relaksasi, mesin ball joint, mesin cross joint, alat uji ketahanan katup, timbangan Lucky, alat uji Kyowa, meja rata, dan meja kaca. Pada layout laboratorium baru lantai 1 terdiri dari lab pengujian sepeda, dan gudang Work in Process sepeda.Pada layout laboratorium baru lantai 2 terdapat Lab uji struktur mikro dan makro, lab uji kompor, lab uji regulator, ruang rapat, gudang, dan kantor. Template layout laboratorium hasil 



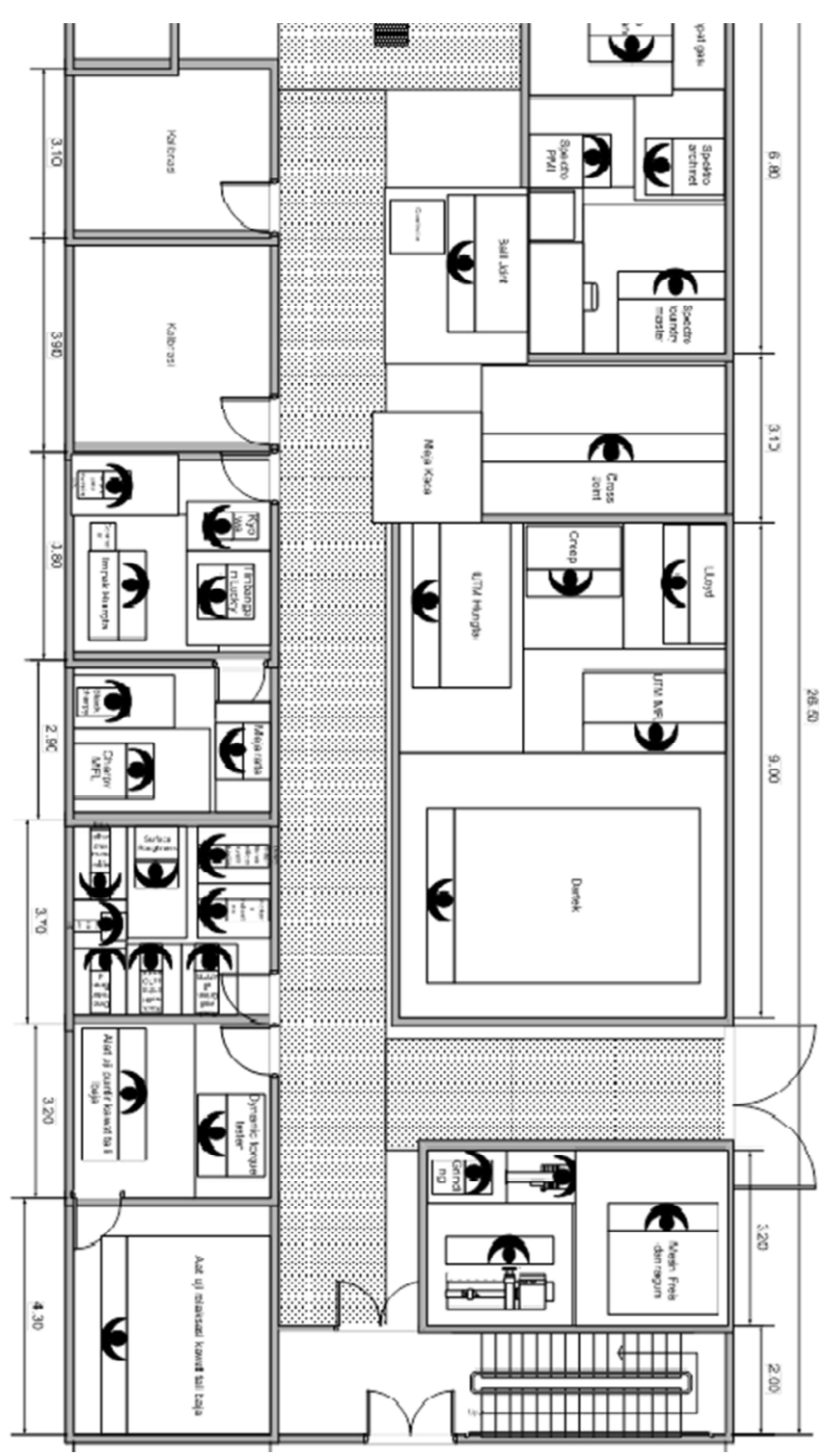

Gambar 6. Layout laboratorium pengujian lama setelah perancangan 


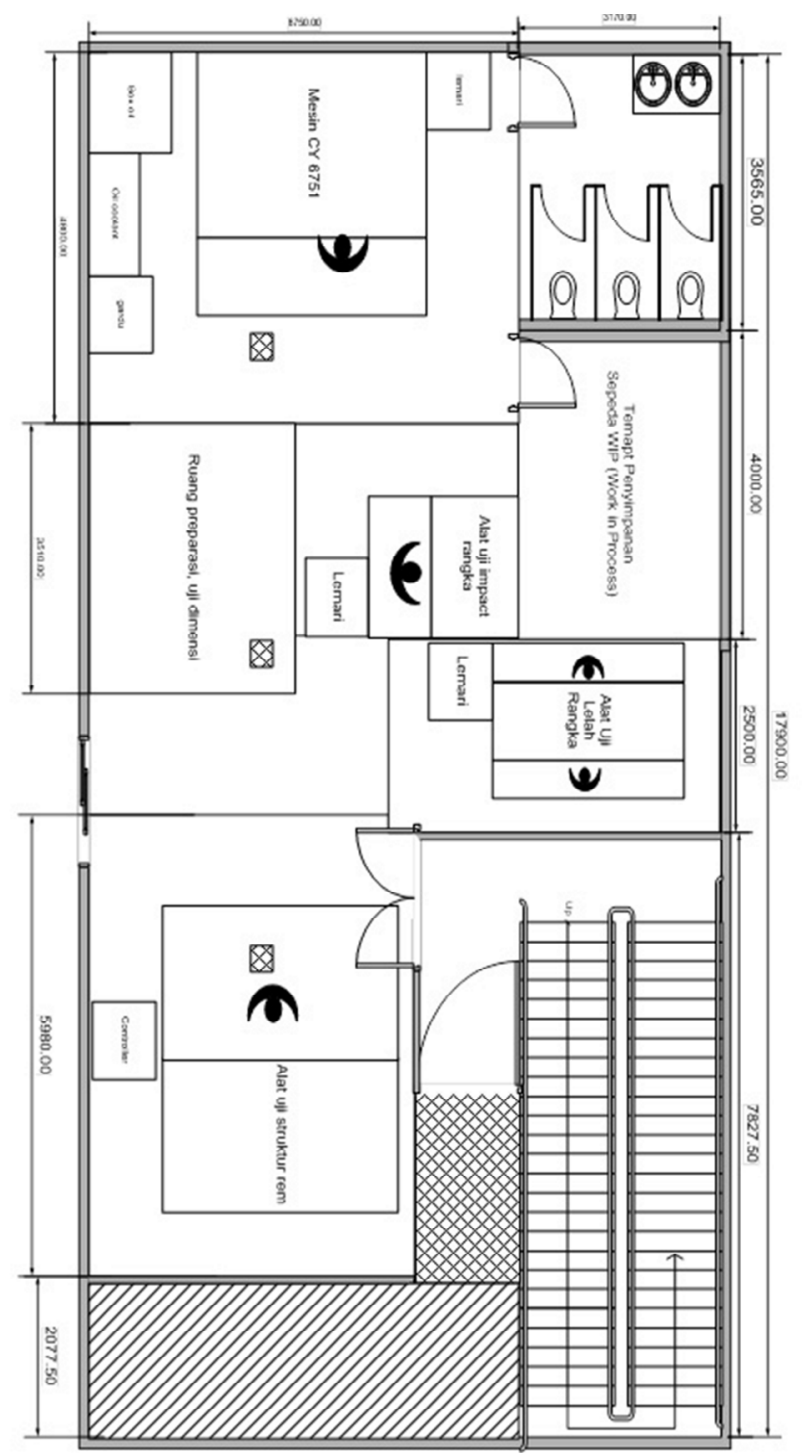

Gambar 7. Layout laboratorium pengujian baru lantai 1 setelah perancangan 


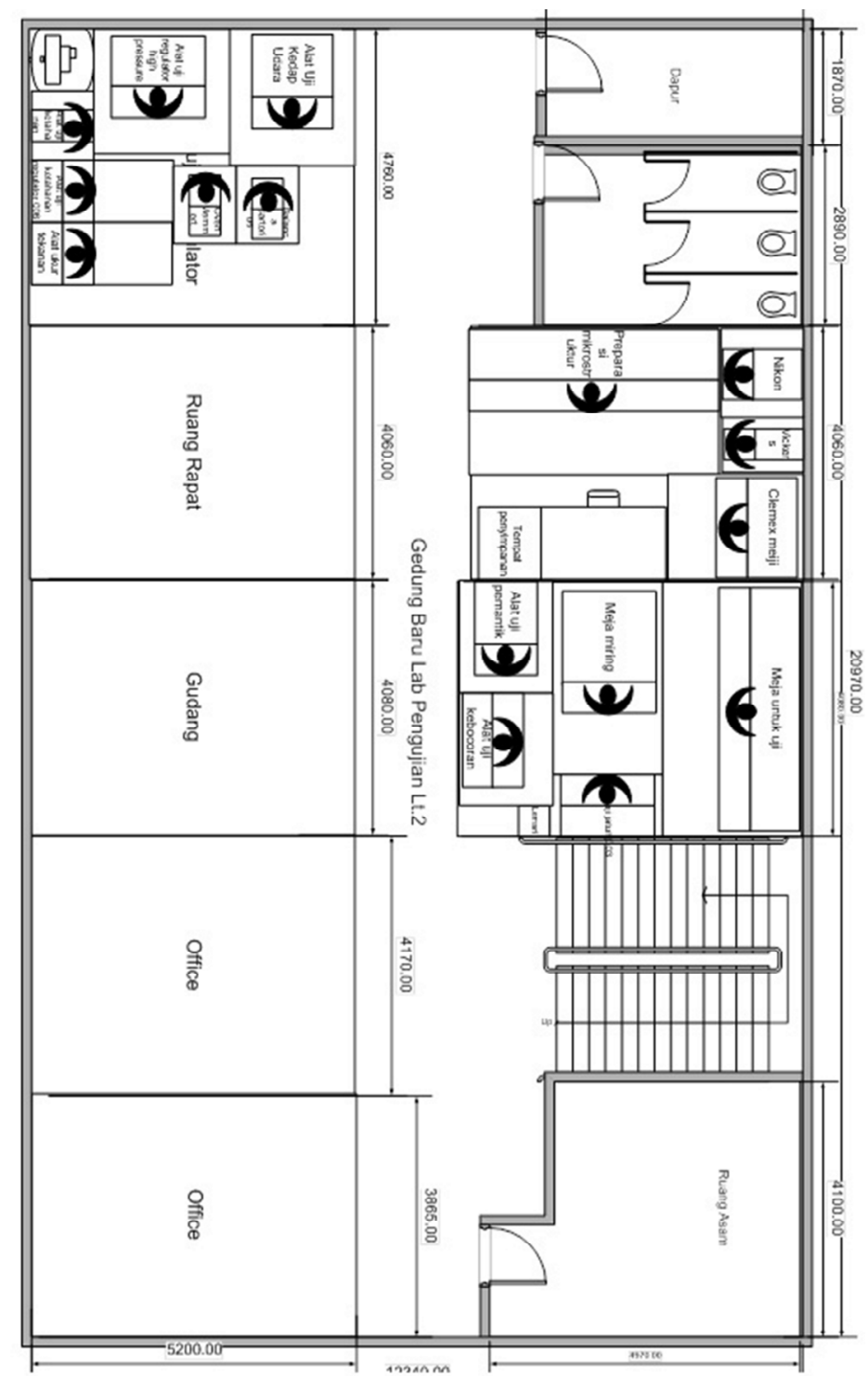

Gambar 8. Layout laboratorium pengujian baru lantai 2 setelah perancangan 


\section{KESIMPULAN DAN SARAN}

Perancangan ulang tata letak fasilitas laboratorium pengujian berdasarkan tingkat hubungan antar fasilitas disusun berdasarkan process layout dan product layout. Fasilitas yang disusun berdasarkan process layout adalah fasilitas yang memiliki fungsi yang sama diletakkan pada area yang sama yaitu fasilitas pengujian kekerasan, spektrometer, struktur mikro dan makro, UTM, Impak, dan perparasi sampel. Sedangkan fasilitas yang disusun berdasarkan product layout adalah fasilitas yang digunakan untuk produk uji yang sama, seperti pengujian sepeda, kompor, dan regulator.

Hasil dari perancangan ulang fasilitas laboratorium pengujian memerlukan pemindahan beberapa fasilitas antara lain:

1. Mesin bubut, mesin grinding, dan mesin gergaji merupakan mesin untuk melakukan preparasi sampel uji. Pada awalnya mesin tersebut diletakkan tidak beraturan sehingga ketiga mesin tersebut dipindahkan dan diletakkan pada area tempat preparasi sampel.

2. Mesin UTM Hungta dan Llyod pada awalnya diletakkan berpisah dengan mesin uji UTM lainnya sehingga perlu dipindahkan ke area pengujian UTM yang berada di laboratorium lama.

3. Cross joint dan ball joint berpindah gedung dari laboratorium pengujian baru lantai $1 \mathrm{ke}$ pengujian lama sedangkan alat uji struktur rem sepeda dari laboratorium pengujian lama berpindah ke area pengujian sepeda di laboratorium pengujian baru lantai 1.

4. Area pengujian spektrometer berpindah dari laboratorium baru lantai 1 ke laboratorium lama.

5. Mesin Charpy MFL dan black charpy merupakan mesin uji impak yang awalnya terletak berjauhan dengan alat uji impak lainnya kemudian berpindah $\mathrm{ke}$ area pengujian impak di laboratorium lama.

6. Alat uji ketahanan katup dari laboratorium pengujian baru lantai 2 berpindah ke Laboratorium pengujian lama.
7. Alat uji kedap udara merupakan alat untuk ppengujian regulator namun terletak berjauhan dengan alat uji regulator lainnya sehingga berpindah ke area pengujian regulator di laboratorium pengujian baru lantai 2.

8. Oven memmert dan balance sartorius yang terletak di laboratorium lama berpindah ke laboratorium pengujian baru lantai 2 .

Untuk mengimplementasikan tata letak fasilitas laboratorium pengujian yang telah dirancang ulang diperlukan dana untuk pemindahan fasilitas seperti membuat pondasi dan membongkar tembok. Selain itu juga diperlukan alat bantu pemindahan mesin/alat seperti trolley, forklift, dan handlift.

\section{DAFTAR PUSTAKA}

Apple, J. (1990). Tata Letak Pabrik dan

Pemindahan Bahan. Bandung: ITB.

Indrianti, N., Marya, E., \& Ristono, A. (2011).

Model Tata Letak Fasilitas Multi-Floor Pada

Industri Jasa. Forum Teknik .

Qoriyana, F., Mustofa, F. H., \& Susanty, S.

(2014). Rancangan Tata Letak Fasilitas Bagian

Produksi Pada CV. Visa Insan Madani. Reka

Integra .

Sarin, S. C., Wang, Y., \& Wang, L. (2009).

Layout Facilities Involving Arbitary-Shaped

Departments. Conference Of The 13th IFAC

Symposium om Information Controls Problem

Manufacturing (hal. 1239). Moscow: IFAC.

Tompkins, J. A., White, J. A., Bozer, Y. A., Frazelle, E. H., Tanhoco, J., \& JaimeTrevino. (1996). Facilities Palnning. Canada: John Willey \& Sons.

wignjosoebroto, S. (1996). Tata letak pabrik dan pemindahan bahan. Surabaya: Guna Widya. 